\title{
HEAT OF FUSION OF ICE. A REVISION
}

\author{
By Nathan S. Osborne
}

\section{ABSTRACT}

The results of measurements of the heat of fusion of ice made at the National Bureau of Standards and published in 1913 and 1915 have been revised by one of the original experimenters, usng more recent data for the heat capacity of water, which is involved in the calculations. The revised value, obtained by weighting the results of four independent series of measurements and expressed in terms of the present calorimetric unit of energy, is

\subsection{INTERNATIONAL JOULES PER GRAM}

with an estimated uncertainty of 0.2 int. $\mathrm{j} / \mathrm{g}$.

The heat of fusion of ice was determined at the National Bureau of Standards about twenty-five years ago $[1,2]^{1}$. The reductions of the observations involved the heat capacity of water, for which the values used were chosen from the data then available. Since more accurate values for the heat capacity of water are now available [3], the values for the heat of fusion of ice are subject to revision. It has been suggested that such a revision, having the benefit of the interpretation of the experimenters themselves, would be helpful by combining all of the results into a single definitive value expressed in terms of the present calorimetric unit of energy, the international joule.

The value of heat capacity of water does not enter as a direct factor but affects parts of the calorimetric process depending on which one of the several methods was used in the two original investigations $[1,2]$. This work was done at a time when it was not fully appreciated that the use of calories as heat units would complicate not only the original reductions but future revisions as well. For this reason the following description of the revisions is likely to appear complicated.

In these two investigations three essentially different methods were used. In the first investigation, published in 1913, a calorimeter with stirred water as the calorimetric medium was used. A controlled jacket permitted heat leak to be accounted for. Two series of measurements were made by the electric-heating method and one series by the method of mixtures. The samples of ice were precooled, so that initial temperatures were known and accounted for in the reductions. The corrections which can be made now to the data as assembled in tables 3 and 5 of the original paper [1] are to reevaluate the heat supplied to bring the ice to $0^{\circ} \mathrm{C}$ and to bring the water formed from $0^{\circ} \mathrm{C}$ to the final temperatures of the various experiments.

\footnotetext{
1 Figures in brackets indicate the literature references at the end of this paper.
} 
For the ice correction a tentative value of $0.52 \mathrm{cal} / \mathrm{g}-{ }^{\circ} \mathrm{C}$ was taken at the time as an approximation to the specific heat of ice in the range from $0^{\circ}$ to $-3.78^{\circ} \mathrm{C}$. In the second investigation, published in 1915 [2], the heat capacity of ice was measured in international joules per gram degree and was finally expressed by the equation

$$
C_{p}=0.5057+0.001863 t \text { cal }_{20} / \mathrm{g}^{\circ}{ }^{\circ} \mathrm{C} \text {, }
$$

where $C_{p}$ is specific heat at 1 -atm pressure, $t$ is centigrade temperature, and the calorie $e_{20}$ was taken as equal to 4.183 int. $j$. For use in the present revision, this equation is now converted back to international joules thus

$$
C_{p}=2.1153+0.00779 t \text { int. } \mathrm{j} / \mathrm{g}-^{\circ} \mathrm{C} \text {. }
$$

For recomputing the water correction, the table given in a recent publication by Osborne, Stimson, and Ginnings [3] is used (table 6, page 238).

The heat supplied in these two series by the electric method was furnished by current in an electric-heating coil, and was measured by use of a potentiometer, a standard cell, and a standard resistor, thus obtaining the power, which, with the observed time, gave the heat added in international joules. This energy per gram of ice as originally corrected for heat leak, temperature change of calorimeter, stirring energy, and heat capacity of the ice holder is given in column 2 of tables 1 and 2, expressed in a nominal 15-degree calorie of 4.187 int. $j$. In column 3 these data are converted back to international joules per gram. The heat per gram absorbed by the melted ice, as revised by the new heat-capacity data, is given in column 4 , and the heat absorbed by the ice from the initial temperature to $0^{\circ} \mathrm{C}$ is given in column 5. The corrections of -1.52 and -7.94 int. $\mathrm{j} / \mathrm{g}$ for $-0.72^{\circ}$ and $-3.78^{\circ}$, respectively, in tables 1 and 2 are next applied giving the final values for heat of fusion in column 6 .

\begin{tabular}{|c|c|c|c|c|c|}
\hline $\begin{array}{l}\text { Final tem- } \\
\text { perature, } t_{2}\end{array}$ & \multicolumn{2}{|c|}{ Ice at -0.72 to water at $t_{2}$} & $\underset{t_{3}}{\text { Water }} 0$ to & $\begin{array}{l}\text { Ice at }-0.72 \\
\text { to water at } 0\end{array}$ & $\begin{array}{l}\text { Ice at } 0 \text { to } \\
\text { water at } 0\end{array}$ \\
\hline $\begin{array}{l}{ }^{\circ} C \\
15.12 \\
14.83 \\
14.60 \\
15.79 \\
15.59\end{array}$ & $\begin{array}{r}c a l_{15} / g \\
95.15 \\
94.92 \\
94.67 \\
95.88 \\
95.67\end{array}$ & $\begin{array}{l}\text { Int. j/g } \\
398.39 \\
397.43 \\
396.38 \\
401.45 \\
400.57\end{array}$ & $\begin{array}{c}\text { Int.j/g } \\
63.57 \\
62.36 \\
61.40 \\
66.37 \\
65.54\end{array}$ & $\begin{array}{l}\text { Int. j/g } \\
334.82 \\
335.07 \\
334.98 \\
335.08 \\
335.03\end{array}$ & $\begin{array}{l}\text { Int. j/g } \\
333.30 \\
333.55 \\
333.46 \\
333.56 \\
333.51\end{array}$ \\
\hline $\begin{array}{l}14.89 \\
14.87 \\
14.96 \\
23.81 \\
23.67\end{array}$ & $\begin{array}{r}94.97 \\
94.96 \\
94.98 \\
103.91 \\
103.75\end{array}$ & $\begin{array}{l}397.64 \\
397.60 \\
397.68 \\
435.07 \\
434.40\end{array}$ & $\begin{array}{l}62.61 \\
62.53 \\
62.90 \\
99.91 \\
99.32\end{array}$ & $\begin{array}{l}335.03 \\
335.07 \\
334.78 \\
335.16 \\
335.08\end{array}$ & $\begin{array}{l}333.51 \\
333.55 \\
333.26 \\
333.64 \\
333.56\end{array}$ \\
\hline $\begin{array}{l}15.53 \\
15.76 \\
15.65\end{array}$ & $\begin{array}{l}95.60 \\
95.81 \\
95.72\end{array}$ & $\begin{array}{l}400.28 \\
401.16 \\
400.78\end{array}$ & $\begin{array}{l}65.29 \\
66.25 \\
65.79\end{array}$ & $\begin{array}{l}334.99 \\
334.91 \\
334.99\end{array}$ & $\begin{array}{l}333.47 \\
333.39 \\
333.47\end{array}$ \\
\hline \multicolumn{5}{|c|}{ Mean of group a } & 333.48 \\
\hline
\end{tabular}

TABLE 1.-Revision of table 3 (1913)

- In obtaining the final mean, this value was given a weight of 4 . 
TABLE 2.-Revision of table 5 (1913)

\begin{tabular}{|c|c|c|c|c|c|}
\hline $\begin{array}{l}\text { Final tem- } \\
\text { perature, } t_{2}\end{array}$ & \multicolumn{2}{|c|}{ Ice at -0.72 to water at $t_{2}$} & $\underset{t_{2}}{\text { Water } 0 \text { to }}$ & $\begin{array}{l}\text { Ice at }-0.72 \\
\text { to water at } 0\end{array}$ & $\begin{array}{l}\text { Ice at } 0 \text { to } \\
\text { water at } 0\end{array}$ \\
\hline $\begin{array}{c}{ }^{\circ} C \\
15.36 \\
14.81 \\
14.88 \\
15.09\end{array}$ & $\begin{array}{l}c a l_{15} / g \\
97.00 \\
96.49 \\
96.54 \\
96.75\end{array}$ & $\begin{array}{l}\text { Int. j/g } \\
406.14 \\
404.00 \\
404.21 \\
405.09\end{array}$ & $\begin{array}{c}\text { Int. j/g } \\
64.58 \\
62.27 \\
62.57 \\
63.44\end{array}$ & $\begin{array}{l}\text { Int.j/g } \\
341.56 \\
341.73 \\
341.64 \\
341.65\end{array}$ & $\begin{array}{l}\text { Int. jlg } \\
333.62 \\
\text { 333. } 79 \\
\text { 333. } 70 \\
\text { 333. } 71\end{array}$ \\
\hline $\begin{array}{l}15.86 \\
14.80 \\
14.81 \\
14.90\end{array}$ & $\begin{array}{l}97.50 \\
96.45 \\
96.47 \\
96.60\end{array}$ & $\begin{array}{l}408.23 \\
403.84 \\
403.92 \\
404.46\end{array}$ & $\begin{array}{l}66.66 \\
62.23 \\
62.28 \\
62.65\end{array}$ & $\begin{array}{l}341.57 \\
341.61 \\
341.64 \\
341.81\end{array}$ & $\begin{array}{l}333.63 \\
333.67 \\
333.70 \\
333.87\end{array}$ \\
\hline $\begin{array}{l}14.93 \\
14.82 \\
14.76 \\
14.71\end{array}$ & $\begin{array}{l}96.61 \\
96.46 \\
96.43 \\
96.35\end{array}$ & $\begin{array}{l}404.51 \\
403.88 \\
403.75 \\
403.42\end{array}$ & $\begin{array}{l}62.77 \\
62.32 \\
62.06 \\
61.86\end{array}$ & $\begin{array}{l}341.74 \\
341.56 \\
341.69 \\
341.56\end{array}$ & $\begin{array}{l}333.80 \\
333.62 \\
333.75 \\
333.62\end{array}$ \\
\hline \multicolumn{5}{|c|}{ Mean of group “ } & 333.71 \\
\hline
\end{tabular}

a In obtaining the final mean, this value was given a weight of 4 .

TABLE 3.--Revision of table 4 (1913)

\begin{tabular}{|c|c|c|c|c|c|c|c|c|}
\hline $\begin{array}{c}\begin{array}{c}\text { Final } \\
\text { tem- } \\
\text { pera- } \\
\text { ture } \\
t_{3}\end{array} \\
{ }^{\circ} \mathrm{C}\end{array}$ & $\frac{\Delta t}{{ }^{\circ} \mathrm{C}}$ & $\begin{array}{l}\text { Ice at }-0.72 \\
\text { to water at } t_{3}\end{array}$ & $\left(\frac{\mathrm{C}_{p}(\mathrm{NBS})}{\mathrm{C}_{p}(\mathrm{HLC})}\right)_{t_{m}}$ & \multicolumn{2}{|c|}{$\begin{array}{c}\text { Ice at }-0.72 \text { to water } \\
\text { at } t_{2}\end{array}$} & \multirow{2}{*}{$\begin{array}{r}\begin{array}{c}\text { Water } \\
0 \text { to } t_{3}\end{array} \\
\text { Int. } j / g \\
50.59 \\
69.64 \\
71.52 \\
73.40 \\
76.37 \\
77.42 \\
75.12 \\
76.41\end{array}$} & \multirow{2}{*}{ 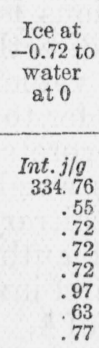 } & \multirow{2}{*}{$\begin{array}{c}\text { Ice at } \\
0 \text { to water } \\
\text { at } 0\end{array}$} \\
\hline $\begin{array}{l}{ }^{\circ} \mathrm{C} \\
12.02 \\
16.57 \\
17.02 \\
\text { 17. } 47 \\
\text { 18. } 18 \\
18.48 \\
17.88 \\
18.19\end{array}$ & $\begin{array}{l}{ }^{\circ} \mathrm{C} \\
3.110 \\
3.447 \\
\text { 2. } 946 \\
5.994 \\
5.732 \\
5.281 \\
\text { 5. } 759 \\
5.301\end{array}$ & $\begin{array}{r}\text { cal }_{15} / g(H L C) \\
92.09 \\
96.56 \\
97.05 \\
97.49 \\
98.20 \\
98.51 \\
97.88 \\
98.21\end{array}$ & $\begin{array}{l}0.9999 \\
\text { 1. } 0002 \\
1.0002 \\
1.0003 \\
1.0003 \\
1.0003 \\
1.0003 \\
1.0003\end{array}$ & $\begin{array}{r}c a l_{15} / g(N B S) \\
92.08 \\
96.58 \\
97.07 \\
97.52 \\
98.23 \\
98.54 \\
97.91 \\
98.24\end{array}$ & $\begin{array}{c}\text { Int. } j / g \\
385.35 \\
404.19 \\
406.24 \\
408.12 \\
411.09 \\
412.39 \\
409.75 \\
411.18\end{array}$ & & & \\
\hline \multicolumn{3}{|c|}{ Mean of groups $\left({ }^{a}\right)$} & & & & & & 333.21 \\
\hline
\end{tabular}

(a) In obtaining the final mean, this value was given a weight of 4 .

\section{TABLE 4.-Revision of table 10 (1915)}

[Aneroid calorimeter]

\begin{tabular}{|c|c|c|c|c|c|c|c|c|c|}
\hline \multirow{2}{*}{$\begin{array}{l}\text { Initial } \\
\text { tempera- } \\
\text { ture, } t_{1}\end{array}$} & \multirow{2}{*}{$\begin{array}{l}\text { Final } \\
\text { tempera- } \\
\text { ture, } t_{2}\end{array}$} & \multicolumn{3}{|c|}{ Water 0 to $t_{2}$} & \multirow{2}{*}{$\underset{\text { ice }}{\text { Mass of }}$} & \multirow{2}{*}{$\begin{array}{l}\text { Correc- } \\
\text { tion per } \\
\text { gram }\end{array}$} & \multirow{2}{*}{$\begin{array}{l}\text { Correc- } \\
\text { tion for } \\
\text { pre- } \\
\text { melting }\end{array}$} & \multirow{2}{*}{$\begin{array}{l}\text { Heat of } \\
\text { fusion }\end{array}$} & \multirow{2}{*}{$\begin{array}{l}\text { Revised } \\
\text { heat of } \\
\text { fusion (a) }\end{array}$} \\
\hline & & $\begin{array}{c}\text { Old } \\
\text { value }\end{array}$ & $\begin{array}{l}\text { New } \\
\text { value }\end{array}$ & $\begin{array}{c}\text { New- } \\
\text { old }\end{array}$ & & & & & \\
\hline $\begin{array}{l}{ }^{\circ} C \\
-3.622 \\
-0.240 \\
-1.635\end{array}$ & $\begin{array}{l}{ }^{\circ} C \\
+4.746 \\
+4.7549 \\
+3.602\end{array}$ & $\begin{array}{l}\text { Int.j } \\
9367.8 \\
8005.1 \\
6993.6\end{array}$ & $\begin{array}{l}\text { Int. } j \\
9410.2 \\
8042.3 \\
7035.6\end{array}$ & $\begin{array}{r}\text { Int. } j \\
42.4 \\
37.2 \\
\$ 2.0\end{array}$ & $\begin{array}{l}8 \\
468.7 \\
399.8 \\
460.7\end{array}$ & $\begin{array}{r}\text { Int. j/g } \\
-0.09 \\
-.09 \\
-.09\end{array}$ & $\begin{array}{r}\text { Int. } . j / g \\
+0.11 \\
+1.67 \\
+0.01\end{array}$ & $\begin{array}{r}\text { Int. j/g } \\
333.14 \\
332.34 \\
333.59\end{array}$ & $\begin{array}{r}\text { Int. j/g } \\
333.16 \\
333.92 \\
333.51\end{array}$ \\
\hline
\end{tabular}

(a) In obtaining the final mean, these values were given weights of 1,1 , and 2, respectively.

In revising the data obtained by the method of mixtures, given in table 4 of the 1913 report, the first step is to reevaluate the heat taken up by the ice from its initial temperature to the final temperature of the calorimeter. This was measured by the observed change of temperature of the calorimeter when the ice was added, and was evaluated in 15-degree calories according to the table of heat capaci- 
ties given by H. L. Callendar [4] in 1912. These values, as originally given, with corrections applied for heat leak, stirring energy, etc., are shown in column 3 of table 3 . In column 4 the ratio is shown of the heat capacity of water according to the new NBS data to the heat capacity given by Callendar, at the mean temperature of the experiment, both in 15-degree calories.

These factors are applied to the figures in column 3, giving the figures in column 5, which are then converted in column 6 to international joules per gram by use of the equivalent from the NBS data, i. e., the heat capacity at $15^{\circ} \mathrm{C}$ is equal to 4.1850 int. $\mathrm{j} / \mathrm{g}^{-}{ }^{\circ} \mathrm{C}$. The remainder of the revision is similar to that of table 1 .

In connection with the later investigation [2], three measurements of heat of fusion were made in the electrically heated heavy-copper calorimeter (aneroid). The main revision of these calculations is the revaluation of the heat taken up by the water from $0^{\circ} \mathrm{C}$ to $t_{2}$. The old and new values for the entire mass of water are given in columns 3 and 4 of table 4 and their differences in column 5 . The corresponding corrections per unit mass of ice are given in column 7. The corrections for premelting of part of the ice, as determined in the specificheat measurements, are given in column 8 . The sum of the two corrections is applied to the original value, as given in column 9, taken directly from column 15 of the original publication. The revised values are found in column 10.

In order to deduce a single figure for the heat of fusion representing an interpretation of the entire amount of experimental data, some relative weighting of experiments or groups must be adopted. This is an arbitrary choice, based on the combined judgment of two of the original authors. Each of the first three groups of measurements in the first investigation is taken as an independent unit with a relative weight of 4 . In the second investigation the first two experiments are each given a weight of one and the last a weight of two. According to this weighting, the general weighted mean is $333.48 \mathrm{int} . \mathrm{j} / \mathrm{g}$.

The revised figure can therefore be taken as 333.5 int. $\mathrm{j} / \mathrm{g}$, with an uncertainty of 0.2 int. $\mathrm{j} / \mathrm{g}$, which has been estimated to include both accidental and systematic errors.

[1] D. R. Harper 3d, and N. S. Osborne, Latent heat of fusion of ice, H. C. Dickinson, Bul. BS 10, 235 (1914) S209.

[2] H. C. Dickinson and N. S. Osborne, Specific heat and heat of fusion of ice, Bul. BS 12, 49 (1915-16) S 248.

[3] Nathan S. Osborne, Harold F. Stimson, and Defoe C. Ginnings, Measurements of heat capacity and heat of vaporization of water in the range $0^{\circ}$ to $100^{\circ} \mathrm{C}$, J. Research NBS 23, 197 (1939) RP1228.

[4] H. L. Callendar, On the variation of the specific heat of water with experiments by a new method. Phil. Trans. Roy. Soc. (London) [A] 212, 1 (1912).

Washington, October 17, 1939. 